\title{
Mast cell chymase promotes cell proliferation and expression of certain cytokines in a dose-dependent manner
}

\author{
XIANGLIN DONG, JUNJIE CHEN, YANGE ZHANG and YING CEN \\ Department of Burns and Plastic Surgery, West China Hospital, Sichuan University, Chengdu, Sichuan 610041, P.R. China
}

Received December 21, 2011; Accepted March 21, 2012

DOI: $10.3892 / \mathrm{mmr} .2012 .851$

\begin{abstract}
Wound healing is a complex process, with various intracellular molecules and cytokines involved. Chymase is a chymotrypsin-like serine protease originally found to be a mast cell protease. In this study, to further investigate the role of chymase in the process of wound healing, the effects of chymase on cell proliferation and cytokine activation in human skin fibroblasts were determined. To determine cell proliferation, MTT assay was employed. The cells were harvested and total proteins were extracted and detected by western blotting. It was found that in vitro cell treatments with chymase led to dose-dependent increases of skin fibroblast proliferation. Moreover, the treatment of cells with chymase for $6 \mathrm{~h}$ induced dose-dependent increases in the expression levels of transforming growth factor (TGF) $-\beta_{1}$ and interleukin (IL)-1 $\beta$, although higher doses $\left(120 \mathrm{ng} / \mathrm{ml}\right.$ for TGF- $\beta_{1} ; 60$ and $120 \mathrm{ng} / \mathrm{ml}$ for IL-1 $\beta$ ) did not facilitate the detected cytokine expression. In addition, treatment for longer periods of time (12 or $24 \mathrm{~h}$ ) did not increase TGF- $\beta_{1}$ or IL-1 $\beta$ expression. The results from our study will strongly facilitate the understanding of the roles of chymase in the process of wound healing.
\end{abstract}

\section{Introduction}

Wound healing consists of multiple processes, such as inflammation, proliferation and maturation (1). These molecular processes are characterized by certain molecular events involved in the participation of particular molecules. Negative effects on the wound healing process result in chronic wounds (2). Not only is it a challenge to cure chronic wounds, but they also have adverse effects on the lives of patients. Furthermore, chronic wounds lead to long-term medical costs. Therefore, it is important to facilitate a quick wound healing process and prevent the development of chronic wounds.

Correspondence to: Dr Ying Cen, Department of Burns and Plastic Surgery, West China Hospital, Sichuan University, 37 Guoxuexing, Chengdu, Sichuan 610041, P.R. China

E-mail: ycen99@yahoo.cn

Key words: chymase, human skin fibroblasts, transforming growth factor- $\beta_{1}$
Chymase is a chymotrypsin-like serine protease originally found to be a mast cell protease (3). Mast cell chymase is involved in the processes of tissue fibrosis, such as liver fibrosis (4), cardiac fibrosis $(5,6)$, pulmonary fibrosis $(7)$ and peritoneal adhesion formation in hamsters $(8,9)$. It has been reported that chymase induces the growth of cultured canine Tenon's capsule fibroblasts (10) and mitogenic response in 3T3 fibroblasts (11). However, it is unclear whether chymase plays a role in wound healing, although a previous report suggested that chymase may play a role in burn wound healing in mice (12).

Certain cytokines, such as transforming growth factor (TGF)- $\beta_{1}$ and interleukin (IL)- $1 \beta$, play important roles in the process of tissue formation $(13,14)$. It has been reported that chymase contributes to the release of TGF- $\beta_{1}$ in cardiomyopathic hamsters (15). In rat cardiac fibroblasts, chymase induces profibrotic response via TGF- $\beta_{1} /$ Smad activation (16). Chymase also leads to the activation of paracrine TGF- $\beta_{1}$ signaling upon stimulation of rat serosal mast cells (17). However, it is unknown whether chymase stimulates the expression of TGF- $\beta_{1}$ and IL-1 $\beta$ in the wound healing process.

In this study, human skin fibroblasts were cultured in vitro and treated with chymase at various concentrations. It was found that the cell proliferation was significantly increased by chymase in a dose-dependent manner. Furthermore, a 6-h treatment with $60 \mathrm{ng} / \mathrm{ml}$ chymase had a maximum effect on the stimulation of TGF- $\beta_{1}$ expression. In addition, a 6 -h treatment with $30 \mathrm{ng} / \mathrm{ml}$ chymase had a maximum effect on the stimulation of IL-1 $\beta$ expression.

\section{Materials and methods}

Cell culture. Human skin samples were obtained from fresh surgical specimens from patients (aged 3-7 years), who underwent an elective circumcision at the First Affiliated Hospital of Xinjiang Medical University in Urumqi, China. Skin samples were treated with PBS containing ampicillin and streptomycin sulfate. The epidermis and subcutaneous fat were rinsed off from the skin samples with PBS. The skin samples in small pieces $\left(\sim 1 \mathrm{~mm}^{3}\right)$ were incubated in the culture flasks containing DMEM, $200 \mathrm{U} / \mathrm{ml}$ collagenase and $300 \mathrm{U} / \mathrm{ml}$ haluronidase at $4^{\circ} \mathrm{C}$ overnight.

Cells were treated with PBS containing $0.25 \%$ trypsinase and $0.02 \%$ EDTA at $37^{\circ} \mathrm{C}$, terminated by the addition of FBS, and then collected by centrifugation at $1,000 \mathrm{x} \mathrm{g}$ for $10 \mathrm{~min}$. The collected cells were incubated in $20 \%$ FBS (Sigma 
Chemical Co., St. Louis, MO, USA) at $37^{\circ} \mathrm{C}$ for $6-8 \mathrm{~h}$, followed by continued culture in DMEM medium containing $10 \% \mathrm{FBS}$. The medium was changed every 2-3 days. Cell growth and morphological developments were observed under an inverted microscope. Cells cultured for 3-6 passages were used for further study.

MTT assay. To determine cell proliferation, MTT assay was employed. Cells in the logarithmic phase were prepared as a single-cell suspension for inoculation into 96-well plates. Cell density was adjusted to $2.5 \times 10^{4} / \mathrm{ml}$, and $200 \mathrm{ml}$ of the suspension was added to each well. Upon cell adherence, DMEM containing $10 \%$ calf serum was used instead. The cells were divided into six groups. Chymase (Sigma Chemical Co.) dissolved in DMEM was added to five groups at $7.5,15$, 30, 60 and $120 \mathrm{ng} / \mathrm{ml}$, respectively, and DMEM alone was added to the control group. There were six parallel samples for each group. Cells were cultured for another 6, 12 or $24 \mathrm{~h}$ before analyses. At the end of incubation, $20 \mathrm{ml}$ of $0.5 \%$ MTT were added to each well, followed by incubation at $37^{\circ} \mathrm{C}$ for $4 \mathrm{~h}$. The supernatants were discarded, and $150 \mathrm{ml}$ of DMSO were added into each well. The plates were shaken for $10 \mathrm{~min}$ to dissolve blue formazan crystals. The growth status and morphological changes of the cells were detected under an inverted microscope. The absorbance was determined at $490 \mathrm{~nm}$ (optical density value) using a Synergy HT microplate reader (Molecular Devices, Sunnyvale, CA, USA).

ELISA. Cells were cultured for 6, 12 and 24 h with chymase in different concentrations, respectively. The levels of collagen type $\mathrm{I}$ in the medium were determined using the ELISA kit (BD Biosciences, Franklin Lakes, NJ, USA), according to the manufacturer's instructions. Briefly, ELISA plates were coated with collagen type I antibody (cat\#: sc-8784-R; 1:500; Santa Cruz Biotechnology, Santa Cruz, CA, USA) and non-specific binding sites were blocked with PBS-bovine serum albumin. Collagen type I standards or medium samples were then added to the wells ( $100 \mathrm{ml} /$ well) and incubated for $2 \mathrm{~h}$ at room temperature. All samples and standards were measured in triplicate.

Western blotting. Cells were harvested and total proteins were extracted. The proteins were separated with 12\% SDS-PAGE gels and transferred to PVDF membranes. Western blotting was performed according to the manual of the Western Breeze Chromogenic Western Blot Immunodetection kit (Invitrogen, Carlsbad, CA, USA). Briefly, the PVDF membranes were incubated for $1 \mathrm{~h}$ at $4^{\circ} \mathrm{C}$ with the primary antibody after blocking with block solution. The primary antibodies used in this study were human anti-TGF- $\beta_{1}$ (cat\#: sc-146; 1:500; Santa Cruz Biotechnology), human anti-IL-1 $\beta$ (cat\#: sc-7884; 1:500; Santa Cruz Biotechnology) and human anti-GAPDH (cat\#: sc-25778; 1:500; Santa Cruz Biotechnology). After incubation with the primary antibody, the membranes were probed with the appropriate alkaline phosphatase-conjugated secondary antibody (anti-mouse or anti-rabbit; 1:20,000; Invitrogen), and then incubated with BCIP/NBT substrate for alkaline phosphatase until the appearance of a purple band. The efficiency of the transfer was confirmed by staining the membrane with Ponceau $\mathrm{S}$. The relative intensity of the immunoreactive bands was quantified using a computer-assisted densitometry program (BioRad Tech, Hercules, CA, USA).

Statistical analyses. The results are expressed as the means \pm standard deviation (SD). Analysis of variance and Dunnett's t-test were performed to evaluate the differences between groups, using SPSS10.0 software. Statistical differences were considered to be significant when the p-value was $<0.05$.

\section{Results}

Chymase facilitates the proliferation of skin fibroblasts. To investigate whether chymase affects the proliferation of human skin fibroblasts, cells were treated with chymase at various concentrations $(0,7.5,15,30,60$ and $120 \mathrm{ng} / \mathrm{ml})$. The morphological changes of the cells treated with or without chymase for 6,12 or $24 \mathrm{~h}$ were observed under an inverted microscope. It was found that the untreated human skin fibroblasts exhibited long, bipolar shapes, but grew slowly during the time course from 6 to $24 \mathrm{~h}$ (Fig. 1A). However, when the cells were treated with gradually increasing concentrations $(7.5,15,30,60$ and $120 \mathrm{ng} / \mathrm{ml})$ of chymase for different times $(6,12$ or $24 \mathrm{~h})$, it was observed that the cells proliferated more rapidly and that the intercellular space decreased at a faster rate compared to the untreated cells. All of these results suggest that treatments with chymase significantly stimulate the proliferation of skin fibroblasts.

To quantify the effects of chymase on skin fibroblasts in vitro, MTT assays were performed. As shown in Fig. 1B, MTT assay results indicated that, compared to the untreated cells ( $0 \mathrm{ng} / \mathrm{ml}$ chymase), the proliferation of the cells treated with chymase $(7.5,15,30,60$ and $120 \mathrm{ng} / \mathrm{ml})$ was significantly increased at all of the detected time-points $(6,12$ or $24 \mathrm{~h})$ $(\mathrm{p}<0.01)$. Furthermore, the cell proliferation was increased in a dose-dependent manner. All of these experiments were repeated three times with similar results.

Chymase increases the expression of TGF- $\beta_{1}$ and $I L-1 \beta$ in skin fibroblasts. The experiments shown above suggest that chymase facilitates the proliferation of skin fibroblasts. It is known that the regulation of cell proliferation is often tightly correlated with changes in the levels of cytokines. To detect whether chymase affects the levels of cytokines in the treated cells, total proteins of cells treated with or without chymase for 6,12 or $24 \mathrm{~h}$ were harvested. Western blotting was performed to determine TGF- $\beta_{1}$ and IL-1 $\beta$ levels, using GAPDH as the loading control (Fig. 2A). The band densities were measured and the density ratios of TGF- $\beta_{1}$ to GAPDH and those of IL- $1 \beta$ to GAPDH from three repeated experiments are presented in Fig. 2B and C, respectively.

As shown in Fig. 2A and B, detection at $6 \mathrm{~h}$ post-treatment indicated that, compared to the untreated cells, the expression of TGF- $\beta_{1}$ was up-regulated in the cells treated with chymase $(7.5,15,30$ and $60 \mathrm{ng} / \mathrm{ml})$ in a dose-dependent manner $(\mathrm{p}<0.01)$. Higher doses $(120 \mathrm{ng} / \mathrm{ml})$ or treatment for longer periods of time (12 or $24 \mathrm{~h}$ ) did not enhance the up-regulation. Therefore, these results suggest that the expression of TGF- $\beta_{1}$ is up-regulated in cells treated with chymase for $6 \mathrm{~h}$ in a dosedependent manner when the dose level is $<60 \mathrm{ng} / \mathrm{ml}$. A dose $>60 \mathrm{ng} / \mathrm{ml}$ does not increase the up-regulation. 


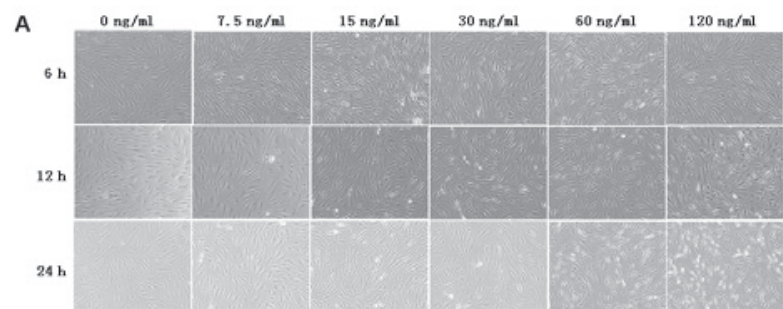

B

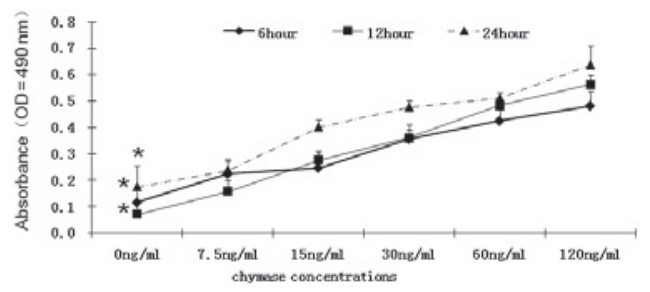

Figure 1. Chymase facilitates fibroblast proliferation. (A) Fibroblasts were treated with chymase at various concentrations $(0,7.5,15,30,60$ and $120 \mathrm{ng} /$ $\mathrm{ml})$. Cells were observed under an inverted microscope at three different timepoints $(6,12$ and $24 \mathrm{~h}$ ) (magnification, $x 400)$. (B) The effects of chymase on fibroblast proliferation were measured by MTT assay. Cells were treated with chymase $(0,7.5,15,30,60$ and $120 \mathrm{ng} / \mathrm{ml})$ for 6,12 or $24 \mathrm{~h}$. Cell proliferation was detected by MTT assay. Data represent the means \pm SD ( $\left.{ }^{*}<0.05\right)$.

As shown in Fig. 2A and C, detection at $6 \mathrm{~h}$ post-treatment indicated that, compared to the untreated cells, the expression of IL-1 $\beta$ was increased in the cells treated with chymase (7.5, 15 and $30 \mathrm{ng} / \mathrm{ml})$ in a dose-dependent manner $(\mathrm{p}<0.01)$. Higher doses $(60$ and $120 \mathrm{ng} / \mathrm{ml})$ or treatment for longer periods of time (12 or $24 \mathrm{~h}$ ) did not increase IL-1 $\beta$ expression effectively. These results suggested that a 6 -h treatment with $30 \mathrm{ng} / \mathrm{ml}$ chymase had a maximum effect on the stimulation of IL-1 $\beta$ expression.

Effect on the collagen synthesis of skin fibroblasts. Previous studies have reported that mast cell chymase activates the expression of matrix metalloproteinases (MMP)2 and MMP9, and therefore facilitates the degradation of the extracellular matrix (18). However, its effect on type I collagen secreted by skin fibroblasts remains unclear. To determine the effect of chymase treatment on the levels of collagen type I in cultured skin fibroblasts, skin fibroblasts were treated with chymase at various concentrations and collagen levels were analyzed by ELISA. The ELISA results indicated that the expression levels of collagen type I were similar at all the concentrations of chymase for 6, 12 and $24 \mathrm{~h}$ (p>0.05) (Fig. 3), suggesting that chymase does not significantly affect the levels of collagen type I in cultured skin fibroblasts.

\section{Discussion}

Skin fibroblasts are the main cell type involved in the process of human wound healing (19). Although it is known that chymase simulates the proliferation of rat cardiac fibroblasts (12), it is not clear whether chymase plays a role in human skin fibroblasts. In this study, the effects of chymase on skin fibroblasts in vitro were investigated. It was found that in vitro cell
A

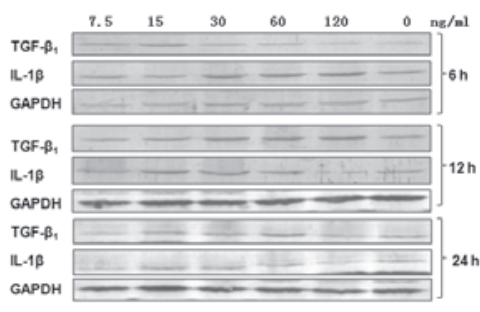

B

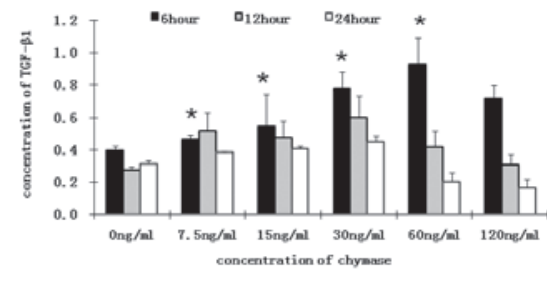

C

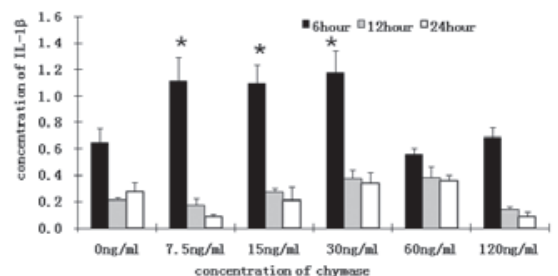

Figure 2. Chymase affects the expression of TGF- $\beta_{1}$ and IL- $1 \beta$ proteins in cultured skin fibroblasts. (A) Western blots showing the levels of TGF- $\beta_{1}$, IL-1 $\beta$ and GAPDH in human skin fibroblasts treated with various concentrations of chymase $(0,7.5,15,30,60$ and $120 \mathrm{ng} / \mathrm{ml})$ for 6,12 or $24 \mathrm{~h}$. (B) Expression of TGF- $\beta_{1}$ in comparison to GAPDH expression ( $\left.\mathrm{p}<<0.01\right)$. All data are presented as the means \pm SD. (C) Expression of IL-1 $\beta$ in comparison to GAPDH expression $\left({ }^{*} \mathrm{p}<0.01\right)$. All data are presented as the means \pm SD.

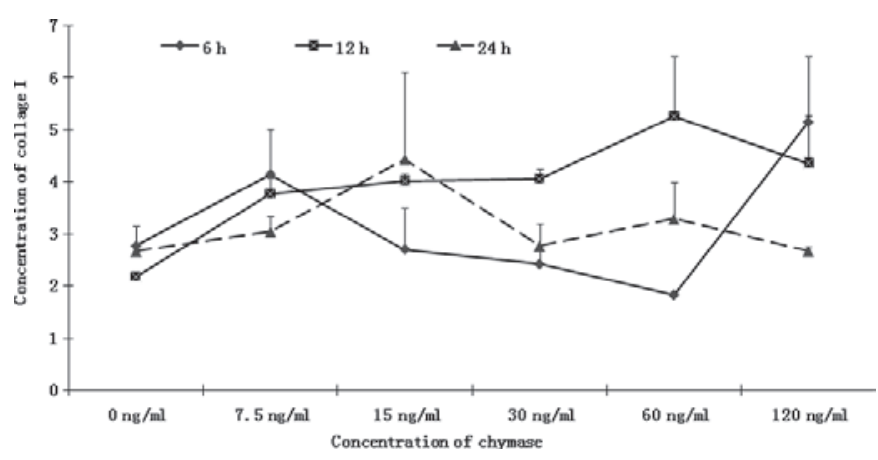

Figure 3. Expression of collagen type I in cultured skin fibroblasts treated with chymase. No significant effect was observed in the groups treated with various concentrations of chymase $(0,7.5,15,30,60$ and $120 \mathrm{ng} / \mathrm{ml})$ for 6,12 and $24 \mathrm{~h}$ $(\mathrm{p}>0.05)$.

treatments with chymase led to a dose-dependent increase in skin fibroblast proliferation (20). Moreover, it was found that cell treatments with chymase for $6 \mathrm{~h}$ induced dose-dependent increases in the expressions of TGF- $\beta_{1}$ and IL- $1 \beta$, although higher doses $\left(120 \mathrm{ng} / \mathrm{ml}\right.$ for TGF- $\beta_{1} ; 60$ and $120 \mathrm{ng} / \mathrm{ml}$ for IL-1 $\beta$ ) did not further enhance the up-regulation of cytokine expression. In addition, treatment for longer periods of time (12 or $24 \mathrm{~h}$ ) did not increase TGF- $\beta_{1}$ or IL-1 $\beta$ expression. Our results will strongly facilitate the understanding of the roles of chymase in the process of wound healing.

In the present study, we found that chymase significantly increased the expression of TGF- $\beta_{1}$ and IL- $1 \beta$ in skin fibro- 
blasts. However, when the cells were treated with chymase at higher concentrations $\left(120 \mathrm{ng} / \mathrm{ml}\right.$ for TGF- $\beta_{1} ; 60$ and $120 \mathrm{ng} /$ $\mathrm{ml}$ for IL-1 $\beta$ ), the stimulatory effects of cytokine expression by chymase were slightly decreased. This is possibly due to the fact that cytokines are regulated only to a limited extent.

It was previously reported that chymase may contribute to wound healing in mice $(12,21)$. We found that in vitro cell treatments with chymase led to a dose-dependent increase in skin fibroblast proliferation. Furthermore, cell treatments with chymase for $6 \mathrm{~h}$ induced dose-dependent increases in the expressions of TGF- $\beta_{1}$ and IL-1 $\beta$. These in vitro data provide the necessary basis for further studies on how to positively regulate the wound healing process by controlling the concentration of chymase in vivo.

\section{Acknowledgements}

The authors thank Dr Tao Liu and Dr Chuanshan Zhang from the laboratory of The First Affiliated Hospital of Xinjiang Medical University.

\section{References}

1. Gieringer M, Gosepath J and Naim R: Radiotherapy and wound healing: Principles, management and prospects. Oncol Rep 26: 299-307, 2011.

2. Szolnoky G, Eros G and Szentner K: Healing of acute and chronic wounds: lymphatics may matter. J Invest Dermatol 131: S6, 2011.

3. Lagunoff D and Benditt EP: Proteolytic enzymes of mast cells Ann NY Acad Sci 103: 185-198, 1963.

4. Komeda K, Takai S, Jin DN, et al: Chymase inhibition attenuates tetrachloride-induced liver fibrosis in hamsters. Hepatol Res 40 832-840, 2010.

5. Takai S, Jin D, Muramatsu M, et al: Therapeutic applications of chymase inhibitors in cardiovascular diseases and fibrosis. Eur J Pharmacol 501: 1-8, 2004.

6. Akgul A: Can cardiac fibrosis be prevented? Mast cell inhibition versus anti-chymase activity. Eur J Cardiothorac Surg 35: 553-554, 2009.

7. Takato H, Yasui M, Ichikawa Y, et al: The specific chymase inhibitor TY-51469 suppresses the accumulation of neutrophils in the lung and reduces silica-induced pulmonary fibrosis in mice. Exper Lung Res 37: 101-108, 2011.
8. Okamoto Y, Takai S and Miyazaki M: Chymase inhibitor, BCEAB, suppressed peritoneal adhesion formation in hamster. J Surg Res 107: 219-222, 2002.

9. Okamoto Y, Takai S and Miyazaki M: Oral administration of a novel chymase inhibitor, NK3201, prevents peritoneal adhesion formation in hamsters. Jpn J Pharmacol 90: 94-96, 2002.

10. Maruichi MTS, Sugiyama TUM, Oku HSM, et al: Role of chymase on growth of cultured canine Tenon's capsule fibroblasts and scarring in a canine conjunctival flap model. Exp Eye Res 79: 111-118, 2004.

11. Algermissen B, Hermes B, Feldmann-Boeddeker I, et al: Mast cell chymase and tryptase during tissue turnover: analysis on in vitro mitogenesis of fibroblasts and keratinocytes and alterations in cutaneous scars. Exp Dermatol 8: 193-198, 1999.

12. Nishikori Y, Kakizoe E, Kobayashi Y, et al: Skin mast cell promotion of matrix remodeling in burn wound healing in mice: relevance of chymase. Arch Dermatol Res 290: 553-560, 1998.

13. Klass BR, Grobbelaar AO and Rolfe KJ: Transforming growth factor beta 1 signalling, wound healing and repair: a multifunctional cytokine with clinical implications for wound repair, a delicate balance. Postgrad Med J 85: 9-14, 2009.

14. Zillmer R, Trostrup H, Karlsmark T, et al: Duration of wound fluid secretion from chronic venous leg ulcers is critical for interleukin-1 alpha, interleukin-1 beta, interleukin-8 levels and fibroblast activation. Arch Dermatol Res 303: 601-606, 2011.

15. Takai S, Jin D, Sakaguchi M, et al: A novel chymase inhibitor, 4-[1-([bis-(4-methyl-phenyl)-methyl]-carbamoyl)3-(2-ethoxybenzyl)-4-oxo-a zetidine-2-yloxy]-benzoic acid (BCEAB), suppressed cardiac fibrosis in cardiomyopathic hamsters. J Pharmacol Exp Ther 305: 17-23, 2003.

16. Zhao X, Zheng Q, Guan H, et al: Chymase induces profibrotic response via transforming growth factor- $\beta 1 / \mathrm{Smad}$ activation in rat cardiac fibroblasts. Mol Cell Biochem 310: 159-166, 2008.

17. Lindstedt Y, Shiota J, Hyytiäinen O, et al: Activation of paracrine TGF-betal signaling upon stimulation and degranulation of rat serosal mast cells: a novel function for chymase. FASEB J 15: 1377-1388, 2001.

18. Caughey GH, Raymond WW and Wolters PJ: Angiotensin II generation by mast cell alpha- and beta-chymases. Biochim Biophys Acta 1480: 245-257, 2000.

19. Demirovic D and Rattan SIS: Curcumin induces stress response and hormetically modulates wound healing ability of human skin fibroblasts undergoing ageing in vitro. Biogerontology 12: 437-444, 2011

20. Lang YD, Chang SF and Wang LF: Chymase mediates paraquatinduced collagen production in human lung fibroblasts. Toxicol Lett 193: 19-25, 2010.

21. Ishida K, Takai S, Murano M, et al: Role of chymase-dependent matrix metalloproteinase- 9 activation in mice with dextran sodium sulfate-induced colitis. J Pharmacol Exp Ther 324: 422-426, 2008. 